DOI: https://doi.org/10.34069/AI/2021.38.02.15

\title{
The concept of soft law the role and legal technologies of influence on the legislation of states
}

\section{Концепт "soft law": роль і юридичні технології впливу на законодавство держав}

Received: March 2, 2021

\section{Abstract}

The study aims to establish the role of "soft law" as a tool of legal technology, its importance for the formation of the legal system within the regulation of various types of legal relations. The current pace of development of society requires a rapid response from the authorities to certain situations. Sometimes the settlement of certain legal relations by customary law is insufficient, as the range of such legal relations cannot be covered by national or international acts. In this case, it is advisable to follow the prescriptions of "soft law", which contain general ideas and principles that determine the main vectors of the settlement of legal relations. Besides, "soft law" serves the purpose of harmonization of the legal framework of different states, which results in the creation of related mechanisms of interaction. In the context of the desire for global cohesion, in particular, European integration, the definition of the impact and role of "soft law" on rulemaking processes becomes especially important. The result of this work is to identify the importance of acts of "soft law" for the settlement of various legal relations at both national and international levels; the role of such acts in the implemented European integration
Accepted: April 5, 2021

\author{
Written by: \\ Denys Manko ${ }^{46}$ \\ https://orcid.org/0000-0002-7677-397X \\ Liydmyla Panova ${ }^{47}$ \\ https://orcid.org/0000-0002-1393-8626 \\ Hanna Holovach $^{48}$ \\ https://orcid.org/0000-0002-8474-9128 \\ Viktoriia Kobko-Odarii ${ }^{49}$ \\ https://orcid.org/0000-0001-9302-472X \\ Liliya Radchenko ${ }^{50}$ \\ https://orcid.org/0000-0002-3783-9489
}

\footnotetext{
${ }^{46}$ Doctor of Legal Sciences, Associate Professor, Head of the Department of State and Legal Disciplines of the International Humanitarian University Ukraine, Ukraine.

${ }^{47}$ Ph. D., Associate Professor of Civil Law Department, Taras Shevchenko National University of Kyiv, Ukraine.

${ }^{48}$ Legal adviser, Co LTD "TD "Ukrimport”, Ukraine.

${ }^{49}$ Ph. D., Associate Professor of Department of Political Science and Law of South Ukrainian National Pedagogical University. K. D. Ushinsky, Ukraine.

${ }^{50} \mathrm{Ph}$. D. in Law, Associate Professor; Associate Professor of Civil Law, Institute of Law, Taras Shevchenko National University of Kyiv, Ukraine.
}

\begin{abstract}
Анотація
Дослідження направлене на встановлення ролі «м'якого права» як інструменту юридичної технології, його значення для формування

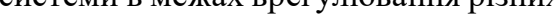
суспі владних структур на ті чи інші ситуації. Інколи врегулювання певних правовідносин звичними нормами права є недостатнім, оскільки спектр таких правовідносин не може охопитися національними або міжнародними актами. В такому випадку доцільно керуватися приписами «м'якого права», які містять в собі загалі ідеї та принципи, що визначають основні вектори розвитку врегулювання правовідносин. Крім того, «м'яке право» слугує меті гармонізації, приведення у відповідність нормативно-правової бази різних держав, що має наслідком створення споріднених механізмів взаємодії. В умовах прагнення до глобального згуртування, зокрема євроінтеграції, визначення впливу та «м «мякого права» на нормотворчі процеси особливого значення. Результат проведеної роботи полягає у виявленні значення актів «м'якого права» для
\end{abstract}


policy; features of legal technologies within the application of "soft law" acts.

Key Words: "Soft law", legal technology, European integration, implementation, harmonization.

\section{Introduction}

The current trend of expanding interaction between states and international associations has necessitated the establishment of effective mechanisms for such interaction, as well as the development of a regulatory framework that will bring the regulation of legal relations within each state and at the level of the international community on pressing issues.

Since the adoption of legal acts at the level of international law requires the implementation of time-consuming multi-component processes (adoption of an act, entry into force, subsequent ratification by states, etc.), the introduction and application of "soft law" is gaining popularity.

"Soft law" norms are understood as institutional, recommendatory norms, which are contained in the relevant sources - first of all in the documents of international intergovernmental organizations. Such norms play an extremely significant supporting role in the formation or definition of opinio juris (legal thought) customary norms, as well as the preparation and development of treaty international law (Butkevych, Mytsyk, \& Zadorozhniy, 2002).

Law, as a system of mandatory rules of conduct introduced or sanctioned by the state, is the most effective regulator of public relations. No other social norms, such as traditions, customs, norms of morality, etc., are able to regulate and ensure the protection of various social relations as the rules of law do (Tkalych, Safonchyk, \& Tolmachevska, 2020).

Thus, "soft law" is embodied in the rules of conduct set out in documents that are not subject to binding legal force, but with the consent of the parties may have certain (indirect) legal consequences, and aimed at achieving practical results or may have such practical significance. In practice, "soft law" is embodied in resolutions, recommendations, appeals, orders, conclusions of relevant organizations, etc. врегулювання різних правовідносин як на національному, так і на міжнародному рівнях; ролі таких актів у здійснюваній політиці євроінтеграції; особливостей юридичних технологій в межах застосування актів «м'якого права».

Ключові слова: «м’яке право», юридична технологія, євроінтеграція, імплементація, гармонізація.

The work aims to characterize the role of "soft law" in the rule-making processes that take place, in particular, with the help of legal technologies. The object of the study is the relationship to the introduction of "soft law" in national law. gender and juvenile policy in different legal systems. The subject of research is the importance of "soft law" as a tool of legal technology.

\section{Theoretical Framework}

This research article highlights works by scientists dedicated to the study of issues related to the research topic.

Thus, in the works of Minchenko (2018) the similar nature of custom and "soft law" is outlined, the analysis of specific features of "soft law" is carried out. Specifically, the author emphasizes that the concept of soft law remains quite controversial in academic science, but in practical terms, the concept is actively used to resolve various relationships that can not be fully regulated by law.

Additionally, Russkikh (2015) paid attention to the importance of soft international law in migration processes, thus noting its supporting role in regulating any relationship. In particular, in his work the autor emphasizes that soft law is a source of customs law of Ukraine and it means a set of legally non-binding international norms created by states, international organizations that do not contradict the basic principles and norms of international law and aimed at regulating international relations.

Moreover, Kyryliuk's (2015) works were based on the regulation by "soft law" of such an important sphere as information. The scientist found that society is currently moving towards complete digitalization and informatization, so the "soft law" aims to fill the gaps in the legislation, which, for some reason, does not 
ensure the proper implementation of the rights and responsibilities of the parties.

Furthermore, Limonova and Arkhipova (2014), considering the activities of cross-border corporations, touched upon the special significance of acts of "soft law" for the functioning of these organizations, which allowed to establish the limits of the use of "soft law" in international economic processes.

Voichenko (2009) researched the characteristics of implementation as a multifaceted legal technology, singled out its types and prospects for development, creating a basis for further analysis of implementation, in particular, in terms of the introduction and use of "soft law".

DiMatteo (2013) provides a survey of the special relationship between international commercial arbitration and soft law instruments. It briefly traces the historical roots of the lex mercatoria to its present enunciations in the Convention on Contracts for the International Sale of Goods (CISG) (1980) and the International Institute for the Unification of Private Law (UNIDROIT): Principles on International Commercial Contracts (1994).

Hillgenberg (1999) examines international acts of soft law. He argues, that international agreements not concluded as treaties play an important role in international relations. Often states prefer non-treaty obligations as a simpler and more flexible foundation for their future relations.

Schwarcz (2019) analyzes the prospects for the development of soft law to regulate international business. He claims, that international business transactions increasingly are being conducted under "soft law" - a term referring to non-state rules that may be aspirational or reflect best practices but are not yet legally enforceable. In part, this shift reflects a decline in cross-border treaty-making, which needs widespread consensus and is subject to lengthy negotiations. Soft law's lack of enforceability, however, is creating uncertainty and undermining predictability. To increase predictability, the author argues for an innovative use of soft law: as a set of rules to choose as the governing "law" of business contracts.

Parella (2020) analyses the reasons why the parties to the relationship choose the classical law or soft law to regulate their relationship. He concludes that while some of these preferences may be attributable to the unique advantages of soft law or hard law, other preferences likely depend on the effects produced by the interaction of both types of law within the broader regulatory landscape.

Baylis (2019) compares the difference in the forms and in the approval processes for hard law and soft law outputs. "While soft law norms "do not impose legally binding obligations," they "may . . . lay the ground, or constitute the building blocks, for the gradual formation of customary rules or treaty provisions» says the author.

At the same time, some issues need further study, in particular on the use of "soft law" in the implementation of legal technologies, its role in harmonizing legislation, influencing the formation of state strategies and policies, the transition from "soft law" to "hard", elimination of conflicts both between the norms of generally recognized official acts and acts of "soft law" and within the acts of "soft law", etc.

\section{Methodology}

The dialectical method revealed the general properties, connections, and patterns that arise in the application of acts of "soft law", in particular, in the framework of European integration processes.

Further, the formal-legal method helped to clarify the essence and content of such legal categories as "soft law", legal technology, transformation, unification, and implementation.

The axiological method served as a basis for substantiating the importance of harmonization of acts of legislation, consolidating the use of acts of "soft law" and the expediency of their consolidation to develop standards of legal regulation.

Moreover, thanks to the comparative law method, it has become possible to compare the application of "soft law" acts in different legal technologies, as well as in different spheres of public life.

Besides, generalization as a method has made it possible to identify the main problems and vectors of development in ensuring the proper implementation of the regulation of relations through "soft law".

Finally, the logical-legal method was used to formulate proposals for the further development of legal regulation by "soft law". 


\section{Results and Discussion}

"Soft law" is a set of optional generally accepted regulations that are characterized by a high level of practical significance and widespread in rulemaking and law enforcement activities. "Soft law" can be considered a kind of indicator of shortcomings and gaps in the existing legal regulation because in the presence of quality and complete settlement of certain relations by traditional sources of law, the need to apply "soft law" would not arise. Today, it is safe to say that it is largely due to soft law that the current regulatory framework is adapted to the existing international situation. Thus, soft law is an effective tool that promotes the recognition and establishment of new international law that would regulate the relations that are most relevant at the moment, thus supporting the effective functioning of the international legal system (Shalinska, 2011).

The peculiarity of "soft law" is that it is designed to address common challenges, the solution of which requires rapid direct coordination, which must be accompanied by the least possible intervention.

The application of "soft law" is also relevant in the case when states cannot unambiguously decide whether there is a need to ratify an international act to resolve the issue of resolving a certain situation if the risk of its recurrence is minimal. In other words, a "soft law" allows you to respond quickly to circumstances that are not typical of the state by borrowing from existing regulatory experience. "Soft law" is characterized by a high level of flexibility and adaptability, through which, in particular, the interpretation of the rules of law, taking into account the specifics of the current situation that has arisen and needs an immediate solution, provided the possibility of reaching a consensus of interests projects (international organizations, states, business, the public, etc.) based on the creation of legal regulators, the effectiveness of which will be ensured not by the formal legal force of norms, but by compliance with the needs of dynamic situations.

According to the theory of prevention of losses, the transition from soft law to hard law creates more severe sanctions, which deter more violations and (because sanctions in the international system are a negative consequence) increase the net losses of the parties. States will opt for soft law when the marginal cost in terms of expected loss from violations exceeds the marginal benefits in terms of restrained violations (Minchenko, 2018).

"Soft law" is not backed by liability for noncompliance, improper enforcement, or violation, i.e. states, in choosing "soft law", do not assume any obligations that could in any way have negative consequences.

According to the authors, the absence of "soft law" sanctions plays an educational and disciplinary role. Thus, with obligations based on a regular contract, there is a risk of being held liable for non-performance or improper performance of the terms of the contract. Soft law emphasizes the trust of contractors, building their relationship on honor and the desire to match each other in status. The unwritten rule of following the rules of "soft law" serves as an indicator of the reputation of the counterparty, as compliance with the established agreements, even without the pressure of possible sanctions, indicates the reliability of the partner.

This points to the common features of "soft law" and custom as sources of law. They are considered to be certain unwritten laws that significantly affect the nature of the relationship and contribute to its settlement at the level of a "gentleman's agreement", i.e. a fair deal.

Specific features of "soft law" should be considered:

1) acts as a regulator of the most dynamic, unstable, changing international relations, which require an appropriate flexible approach;

2) is an operational solution to emerging international problems, while stimulating the rule-making activities of international organizations and states at the level of concluding political agreements;

3) has excellent mechanisms for authorizing, monitoring, and supervising compliance compared to traditional law;

4) is characterized by the specificity of the process and reasons for implementation, which as a result gives them the same status as the transformed rules of the so-called "hard" international law;

5) is accompanied by a tendency to restrain the processes of integration of social processes and harmonization of legislation and the preservation of the sovereignty of individual states, etc. (Russkikh, 2015). 
The main function of "soft law" is regulatory. In this case, the specified regulatory role is recommendatory, i.e. is implemented only in cases of expression of the desire of the subject of legal relations to apply a rule of "soft law".

At the same time, "soft law" is now reflected in many spheres of public life. Thus, according to Kyryliuk (2015), the application of the concept of soft law in the information age will help to understand and take into account at the regulatory level the legal consequences of globalization. In fact, there is a latent crisis of positive international law, which they try not to talk about, because states and existing international organizations can not offer effective alternative means of regulating legal relations in the information sphere, which has no national dimension and is cross-border in nature". Indeed, in the age of the information society, which is developing too fast, it is extremely difficult to trace and settle all relations related to information technology in time, so solving specific issues often requires the application of rules that are not yet provided, as they must undergo a procedure. That is why the application of "soft law" in such a situation allows for independent decisionmaking, taking into account the recommendations adopted by the international community.

The application of "soft law" is also effective in the field of environmental protection, as a significant part of the rules governing this area are set out in the recommendations of international organizations. Thus, even today, the fundamental role in addressing environmental issues is played by the 1992 UN Conference, which proclaimed a significant number of thorough documents, the content of which sets out some comprehensive measures. For example, the Declaration on Environment and Development (United Nations, 1992) proclaims a basic value - human life and well-being depend on the state of the natural environment.

In international economic relations, some areas are currently governed only by "soft law". This category should include the creation and operation of transnational corporations, which play a significant role in the international economy but have not yet been awarded a separate generally accepted and established legal framework for regulating their activities.

Thus, the interstate regulation of the activities of the above organizations is generally carried out based on bilateral investment agreements between the states concerned, which is the most common way to establish relations. At the same time, for example, in the United States, Japan, and the United Kingdom, there is a wellestablished model of such agreements, while Ukraine, in cooperation with cross-border companies, can be guided only by "soft law," which is the basis for concluding individual agreements (Limonova, \& Arkhipova, 2014).

Thus, of great importance for the regulation of cross-border corporations is the Code of Foreign Investment with unified rules of cross-border corporations, created by the Andean Group (Grosse, 1983; Oliver, 1972). The sphere of influence of "soft law" and labor relations has not escaped. The acts adopted by the International Labor Organization, in particular, the International Labor Conventions No. 97 (1949) and No. 143 (International Labor Organization, 1975), are generally recognized. However, these conventions complement the detailed recommendations of the International Labor Organization (ILO) to promote a common course of action for member states on several basic provisions contained in these treaties. Interestingly, although state parties may disregard them, they are obliged to make recommendations to their national authorities for consideration and to inform them of the measures taken on these issues. This dual obligation of conduct is enshrined in Article 19 (6) of the ILO Constitution (1919) and provides an incentive to follow the recommendations, even if they are not formally binding on States parties.

Soft law is also about resolving conflicts, both international and non-international, including ethnic ones. For example, at the international level, the UN Charter (United Nations, 1945) acts as an act of "soft law", giving the UN General Assembly the right to consider general principles of cooperation in support of international peace and security, including principles defining disarmament and arms regulation and to these principles are recommended by the UN or the Security Council. Thus, the General Assembly has the right to create a "soft law" and to extend its effect to influential subjects of international law (Kovaleva, \& Chernichenko, 2011).

Thus, resolutions of the UN General Assembly are an essential regulator of relations. For example, Resolution 58/187 "Protection of human rights and fundamental freedoms in the fight against terrorism" (United Nations, 2003), Resolution 56/24 "General and complete disarmament" (United Nations, 2002), Resolution 43/28 "On the human rights situation in the Syrian Arab Republic" (United Nations, 
2020). Soft law serves as a compromise in cases where states and/or international organizations have to settle relations, but such regulation cannot be formalized in the form of agreements as international legal acts, but their significance goes beyond moral and political obligations. Thus, the "soft law" is an assistant in establishing the rights and obligations of counterparties, which are not enshrined in law but require at least minimal formalization.

The above allows us to conclude that soft law is involved in the application of various legal technologies.

Scientists are currently discussing the definition of "legal technology" and its relationship to "legal technology".

However, according to the author, the most complete and comprehensive characteristic is Kartashov (2000), according to which the composition of modern legal technology is a set of the following elements:

a) a system of appropriate means (legal technique);

b) a system of techniques, methods, and techniques of optimal legal activity (tactics);

c) scientifically substantiated principles, longterm plans, forecasts, and methods of activity (legal strategy);

d) the very actions and operations for the development, adoption, and publication (publication) of legal decisions (acts);

e) procedural forms of activity (legal stages, productions, and regimes);

f) indicators that characterize the quality and efficiency of legal activities, as well as time, financial and other costs of these activities;

g) appropriate types, forms, means and methods of control and supervision over the legality, quality and efficiency of the adopted legal decisions (acts).

According to Isayeva, "legal technology is based on the use of legal techniques, it is a complex, resource-based legal activity, which includes a system of logically interconnected operations, due to the level of development of the legal system of society, based on knowledge of optimal interaction-technical means used to achieve certain legal goals and entails certain legal results.

Legal technology must be understood in two senses: first, as based on certain principles, plans, and forecasts, the process of preparation, execution, publication, and implementation of various legal decisions (acts), which uses the necessary tools, techniques, methods, and techniques of legal activity; secondly, legal technology is a system of knowledge about the optimal, such that can be applied in specific historical conditions and in the prescribed manner legal and technical means, which is reflected in the strategy, tactics, rules, techniques, methods, and techniques of legal activity eligible entities" (Isaeva, 2008).

As stated earlier, acts of "soft law" will regulate a significant number of issues arising in the relationship, so it is impossible not to take such acts into account when creating an act of "hard law".

Thus, within the framework of legal technology, the provisions of "soft law" are reinforced and eventually become acts of "hard law", i.e. they become a clearly established normatively established rule of conduct.

Since "soft law" is generally a source of law created at the level of international law; its greatest application within legal technologies is found in implementation.

Implementation is the process of transposing into law norms and regulations borrowed from other sources, which aims at purposeful organizational and legal activities of states, which is carried out individually, collectively, or within international organizations to timely, comprehensive, and full implementation of their adopted, following international rights of obligations.

The legal literature emphasizes various ways of implementation, such as transformation, referral, incorporation, legitimation, adaptation, and reception.

The most common ways of implementing international law, in particular, the rules of "soft law" in the national legal system are:

- reception, i.e. textual repetition by the rulemaking body of the state of the content of another norm in the article of the normative legal act;

- transformation, which means the processing of the text of the act or its articles with the adoption on this basis of domestic law;

- a reference, which is an indication in a domestic legal act of international law as a source that regulates these reference relations (Voichenko, 2009). 
It is worth noting that, within the framework of the implementation of the "soft law" provisions, the referral can be considered one of the most unsuccessful ways of legal technology, which is difficult to find in practice. Thus, acts of "soft law" do not have the form of a generally accepted source of law, and therefore it is incorrect to refer to them in a normative act.

On the contrary, the most common method of implementation is transformation.

Thus, any normative legal act in a state that seeks to strengthen its position in the international arena and meet generally accepted international standards must be supported, in particular, by the norm of international law. The application of "soft law" acts is not an exception in this case.

The authors believe that a clear example of the application of "soft law" is its application in the development of state policy, in particular, national and international strategies, which, in turn, is a planned driving force for the transformation processes required by society and the state.

Depending on the field of theoretical knowledge or practice, "strategy" means: "the most general mechanism of action that determines the ways to achieve the goal", "sequence of ideas leading to a certain result", "choice of key areas of development that integrates the goals of groups, parties, corporations, cities, states, associations of states". Solovyov defines the state strategy as "a plan that unites all spheres of state activity, comprehensively covers significant aspects of a project and integrates its components" (Solovyov, 2006) contributes to the identification of systemic effects for vital areas of society and the state.

In other words, the strategy is based, in particular, on prescriptions borrowed from "soft law", and as a consequence can itself be considered a norm of "soft law", as it also enshrines the ideas and provisions to be implemented.

For example, the World Health Organization (WHO) plays a significant role in health care. Based on WHO recommendations, a large number of developments and implementations in national legislation are carried out. Thus, the Resolution of the Cabinet of Ministers of Ukraine of December 5, 2018, Resolution No. 1022 approved the State Strategy for the implementation of state policy of providing the population with medicines for the period up to
2025, paragraph 1 of the General Part states that this State Strategy is based on WHO recommendations.

The complexity of the implementation process is caused by several factors, both internal and external. These include the lack of a clear legal framework necessary to regulate the process of implementation and enforcement; the inconsistency of a large number of standards enshrined in national law, international standards (which leads to collisions); the lack of clear definition of the moment from which an international act becomes part of national law (which leads to errors in law enforcement); as well as the lack of a defined place of international acts that do not require parliamentary consent.

At present, Ukraine has chosen a course of European integration, which is accompanied, in particular, by the harmonization of national legislation with the standards of the European Union (hereinafter - the EU). This alignment should be consistent not only with existing regulations adopted within the functioning of the EU but also with "soft law" acts.

Within the framework of the settlement of relations, it is worth noting the contribution of the European Commission, which creates soft law instruments of various kinds (recommendations, conclusions, communications, guidelines, framework acts, and codes of conduct).

Thus, with the help of the fruitful work of the European Commission at the level of "soft law," a significant number of acts have been developed clarifying the scope of Articles 101-102 of the Treaty on the Functioning of the European Union (1957) (prohibition of anti-competitive agreements and abuse of dominant position, respectively) enforcement of EU competition law, the main parameters of merger control governed by Regulation 139/2004 (European Union, 2004), as well as the basics of the EU state aid regime. The above soft law acts must be taken into account when adapting national competition law to the requirements of the relevant law established by the EU, as they are reflected in the interpretation of certain rules.

As a result, the EU Court of Judgment in Case C322/88 (European Union, 1989) Salvatore Grimaldi v Fonds ruled that the recommendations cannot be ignored by national institutions interpreting EU law, as soft law instruments are used not only to interpret binding EU law but also in areas, where the European Union does not have the competence to adopt 
binding legislation, or where a draft act of binding legislation has not been approved by the European Parliament and the Council (or by the Council if special legislative procedures apply in the relevant field) (Association4U, 2018).

While the application of "soft law" of the EU justifies itself at the level of European integration processes within the framework of state policy in this direction, the use of "soft law" of the Council of Europe is a responsibility of Ukraine, which is already part of it.

The most influential "soft law" of the Council of Europe is the recommendations of the Parliamentary Assembly of the Council of Europe, which is an advisory body to the Committee of Ministers. Thus, the Parliamentary Assembly adopts resolutions and other documents that define the main, general areas of activity of the Committee of Ministers, national governments, parliaments, and political parties; develops various international treaties European conventions, which contribute to the formation of the basis of the European legal system. Parliamentary Assembly of the Council of Europe (PACE) (2021) documents are not binding, but they are guided by the Committee of Ministers, national governments, parliaments, and parties.

Also defining are the Council of Europe's human rights standards, which are a kind of "soft law" and consist of the rules enshrined in the Convention for the Protection of Human Rights and Fundamental Freedoms (United Nations, 1950), the European Social Charter (Council of Europe, 1961), the European Charter of Local Self-Government (Council of Europe, 1985) and other conventions and acts of the Council of Europe. For example, in 1987, the Committee of Ministers approved Recommendation No. R (87) 3 (Council of Europe, 1987), which introduced the European Penitentiary Rules, the European minimum standard rules for the treatment of prisoners. It was important in establishing these rules to establish general principles in the field of criminal law policy for all member states of the Council of Europe (Butkevych, Mytsyk, \& Zadorozhniy, 2002).

On a par with the positive trends in the application of "soft law", it should also be noted that such use of it within the framework of legal technologies activates the process of deforming international law, as it in some way displaces the latter as a regulator of relations. States, by recognizing the obligation to use an act of "soft law" gives such an act the status of a quasi- obligation. This creates a policy of pluralism of legal regulators, which are not always subject to the process of unification, as a result of which is brought to a common generally accepted mechanism. Thus, the excessive use of "soft law" acts in cases where there is a clear regulation of relations, can lead to conflicts between the provision of "soft law" and the statutory rule.

The avoidance of conflicts is possible only in the case of timely implementation of such legal technology as unification, which will identify differences and eliminate them by adopting a single act.

Simultaneously, the universality of unification as a mechanism for the development of modern international law requires consideration of the opportunities, limitations, and potential risks of soft international law as a way of normative unification and control over the implementation of unified norms and standards.

\section{Conclusions}

1. "Soft law", although not part of the generally accepted sources of law, is an integral part of the legal regulation of relations in society. Thus, soft law acts are reflected in various areas: environmental protection, the activities of multinational corporations and other economic organizations, the settlement of armed, religious, racial, linguistic, and other mass conflicts, labor organization, health care, etc.

2. Due to the specific nature of the adoption of acts of "soft law" and their recognition by the parties to the relevant legal relationship, to determine and establish an exclusive list of types of acts of "soft law" is impossible, as such acts are adopted taking into account the specifics of the situation. which they were accepted. As a rule, "soft law" is fixed in the form of recommendations, conclusions, and resolutions.

3. "Soft law" should be considered a regulator not only of the relevant legal relationship but also of the general state of ownership and sufficiency of the international and national legal framework, as "soft law" is relevant in the absence of formal legal regulation or its application is impractical and causes many difficulties.

4. Soft law is closely linked to legal technologies such as harmonization and implementation. Thus, at present, states, in particular, within the membership of the relevant international communities, 
undertake to transpose into their legislation the norms and regulations contained in the acts of "soft law". Such harmonization is a positive experience, as it approximates the laws of different states not only to each other but also creates a certain standard of regulation, which results in the same solution of issues of a similar nature.

5. Concurrently, a large number of recognized soft law instruments may lead to their excessive accumulation and repetition, as there are no restrictions on the adoption of such acts and the commitment of States to follow them. There is a risk of conflicts both between "soft law" and "hard law" acts and between the "soft law" rules themselves. Given the above, an important step in the introduction and implementation of the regulation of legal relations through acts of "soft law" is the unification of such acts, which will minimize the possibility of creating shortcomings in the international and national legal framework.

\section{Bibliographic references}

Association4U. (2018). Recommendations for Ukrainian public administration bodies on approximation to EU law. Recovered from https://cutt.ly/IlmAtIH.

Baylis, E. (2019). The International Law Commission's Soft Law Influence. FIU Law Review, 13(6), 1007-1025. DOI: https://dx.doi.org/10.25148/lawrev.13.6.6

Butkevych, V.G., Mytsyk, V.V., \& Zadorozhniy, V.V. (2002). International law. Fundamentals of theory. Kyiv: Lybid. Recovered from

http://law.inf.ua/\%D0\%BC\%D1\%96\%D0\%B6

$\% \mathrm{D} 0 \% \mathrm{BD} \% \mathrm{D} 0 \% \mathrm{~B} 0 \% \mathrm{D} 1 \% 80 \% \mathrm{D} 0 \% \mathrm{BE} \% \mathrm{D} 0 \%$ B4\%D0\%BD\%D0\%B5-

$\% \mathrm{D} 0 \% \mathrm{BF} \% \mathrm{D} 1 \% 80 \% \mathrm{D} 0 \% \mathrm{~B} 0 \% \mathrm{D} 0 \% \mathrm{~B} 2 \% \mathrm{D} 0 \%$

BE-

$\% \mathrm{D} 0 \% \mathrm{BE} \% \mathrm{D} 1 \% 81 \% \mathrm{D} 0 \% \mathrm{BD} \% \mathrm{D} 0 \% \mathrm{BE} \% \mathrm{D} 0 \%$ $\mathrm{B} 2 \% \mathrm{D} 0 \% \mathrm{~B} 8$

$\% \mathrm{D} 1 \% 82 \% \mathrm{D} 0 \% \mathrm{~B} 5 \% \mathrm{D} 0 \% \mathrm{BE} \% \mathrm{D} 1 \% 80 \% \mathrm{D} 1 \% 9$ $6 \% \mathrm{D} 1 \% 97-$

$\% \mathrm{D} 0 \% \mathrm{~B} 1 \% \mathrm{D} 1 \% 83 \% \mathrm{D} 1 \% 82 \% \mathrm{D} 0 \% \mathrm{BA} \% \mathrm{D} 0 \%$

B5\%D0\%B2\%D0\%B8\%D1\%87.html

Council of Europe. (1961). European Social Charter.

Recovered from

https://rm.coe.int/168006b642.

Council of Europe. (1985). European Charter of Local Self-Government. Recovered from https://rm.coe.int/168007a088.

Council of Europe. (1987). Recommendation No. R (87) 3. Recovered from https://rm.coe.int/16804f856c.
DiMatteo, L.A. (2013). Soft Law and the Principle of Fair and Equitable Decision Making in International Contract Arbitration. The Chinese Journal of Comparative Law, 1(2), 221$255 . \quad$ Recovered from https://doi.org/10.1093/cjcl/cxt013.

European Union. (1957). Treaty on the Functioning of the European Union. Recovered from https://eur-lex.europa.eu/legalcontent/EN/TXT/?uri=celex\%3A12012E\%2FT

XT.

European Union. (2004). Regulation 139/2004. Recovered from https://eur-lex.europa.eu/legalcontent/EN/ALL/?uri=celex\%3A32004R0139.

European Union. Court. (1989). Salvatore Grimaldi v Fonds: Judgment. Recovered from https://eur-lex.europa.eu/legal-

content/en/TXT/?uri=CELEX\%3A61988CJ032 2.

Grosse, R. (1983). The Andean Foreign Investment Code's Impact on Multinational Enterprises. Journal of International Business Studies, 14(3), 121-133. Recovered from http://www.jstor.org/stable/154694.

Hillgenberg, H. (1999). A fresh look at Soft law. European Journal of International Law, 10(3), 499-515. Recovered from https://doi.org/10.1093/ejil/10.3.499

International Institute for the Unification of Private Law (UNIDROIT). (1994). Principles on International Commercial Contracts. Recovered from

https://www.unidroit.org/index.php?option=com _content\&view=article\&id=513:unidroitprinciples-of-international-commercialcontracts \&catid=91: principles \&Itemid $=549$.

International Labor Organization. (1919). Constitution. Recovered from https://www.ilo.org/dyn/normlex/en/f?p=1000:6 2:0::NO:62:P62_LIST_ENTRIE_ID:2453907:N $\mathrm{O}$.

International Labor Organization. (1949). Migration for Employment Convention. Recovered from https://www.ilo.org/dyn/normlex/en/f?p=NOR MLEXPUB:12100:0::NO::p12100_instrument_i $\mathrm{d}: 312242$.

International Labor Organization. (1975). Migrant Workers (Supplementary Provisions) Convention No. 143. Recovered from https://www.ilo.org/dyn/normlex/en/f?p=NOR MLEXPUB:12100:0::NO::P12100_ILO_CODE :C143.

Isaeva, L.A. (2008). Legal technologies in the activities of the penitentiary system (doctoral thesis). Vladimir Law Institute of the Federal Penitentiary Service, Vladimir. 
Kartashov, V. N. (2000). Legal technique, tactics, strategy and technology (to the question of the ratio). Nizhny Novgorod: Osnova.

Kovaleva, A. A., \& Chernichenko, S. V. (Eds.). (2011). International law. Moscow: Omega-L. ISBN 978-5-8354-0932-7.

Kyryliuk, O.V. (2015). Soft law as a normative basis of the global information society. Current issues of international relations, 125(1), 106-116. Recovered from http://journals.iir.kiev.ua/index.php/apmv/article /viewFile/2664/2368.

Limonova, E.M., \& Arkhipova, K.S. (2014). Transnational corporations: the main stages of development and regulation of their activities in the context of globalization. European vector of economic development, 1(16), 101-109. Recovered from https://eurodev.duan.edu.ua/images/PDF/2014/1 /11.pdf.

Minchenko, O.V. (2018). Soft law as a formalized speech act. Scientific Bulletin of Public and Private Law, 3(1), 24-27. Recovered from http://nvppp.in.ua/vip/2018/3/tom_1/vip31_2018.pdf\#page $=24$.

Oliver, C. (1972). The Andean Foreign Investment Code: A New Phase in the Quest for Normative Order as to Direct Foreign Investment. The American Journal of International Law, 66(4), 763-784. doi: $10.2307 / 2198508$.

Parella, K. (2020). Hard and Soft Law Preferences in Business and Human Rights. AJIL Unbound, 114, 169-178. Recovered from https://doi.org/10.1017/aju.2020.33.

Parliamentary Assembly of the Council of Europe. (2021). Official website. Recovered from https://pace.coe.int/en/.

Resolution 1022. State strategy for the implementation of state policy of providing the population with medicines for the period up to 2025, Cabinet of Ministers, 5 de diciembre de $2018 . \quad$ Recovered from https://zakon.rada.gov.ua/laws/show/10222018-\%D0\%BF\#Text.

Russkikh, T.V. (2015). The concept of soft law in the field of regulation of customs relations in Ukraine (doctoral thesis). Nat. univers. "Odesa Law Academy", Odessa. Recovered from http://dspace.onua.edu.ua/bitstream/handle/1130 0/3243/Diss.pdf? sequence $=4 \&$ is Allowed $=y$.
Schwarcz, S. L. (2019). Soft Law as Governing Law. Duke Law School Public Law \& Legal Theory Series Paper, 8, 307-418. Recovered from https://ssrn.com/abstract $=3307418$ or http://dx.doi.org/10.2139/ssrn.3307418.

Shalinska, I.V. (2011). Acts of "soft law": the concept and significance in the international legal order. Sociology of law, 2, 70-74. Recovered from http://dspace.nbuv.gov.ua/handle/123456789/39 605.

Solovyov, A.I. (2006). Adoption of state decisions. Moscow: KNORUS. ISBN 5-85971224-3.

Tkalych, M., Safonchyk, O., \& Tolmachevska, Y. (2020). Private Law and human rights: New realities. DIXI, 22(2), 1-12. DOI: https://doi.org/10.16925/2357-5891.2020.02.04 United Nations. (1945). The Charter. Recovered from https://www.un.org/en/about-us/un-charter. United Nations. (1950). Convention for the Protection of Human Rights and Fundamental Freedoms. Recovered from https://www.echr.coe.int/documents/convention _eng.pdf

United Nations. (1980). United Nations Convention on Contracts for the International Sale of Goods (CISG). Recovered from https://uncitral.un.org/en/texts/salegoods/conven tions/sale_of_goods/cisg.

United Nations. (1992). Rio Declaration on Environment and Development. Recovered from https://www.un.org/en/development/desa/popul ation/migration/generalassembly/docs/globalco mpact/A_CONF.151_26_Vol.I_Declaration.pdf United Nations. (2002). General and complete disarmament: Resolution 56/24. Recovered from https://www.undocs.org/A/RES/56/24.

United Nations. (2003). Protection of human rights and fundamental freedoms in the fight against terrorism: Resolution 58/187. Recovered from https://undocs.org/en/A/RES/58/187.

United Nations. (2020). General and complete disarmament: Resolution 43/28. Recovered from https://www.undocs.org/A/RES/56/24.

Voichenko, S.V. (2009). Concepts and forms of implementation in modern international law. Current issues of state and law, 46, 363-369. Recovered from http://www.apdp.in.ua/v46/64.pdf. 